\title{
Zircon SIMS U-Pb geochronology of the Lushan terrane: dating metamorphism of the southwestern terminal of the Palaeoproterozoic Trans-North China Orogen
}

\author{
JUN-SHENG LU* ${ }_{\ddagger}$, GUO-DONG WANG*, HAO WANG*, HONG-XU CHEN*, \\ TAO PENG* \& CHUN-MING WU* ${ }^{*} \dagger$ \\ ${ }^{*}$ College of Earth Science, University of Chinese Academy of Sciences, P.O. Box 4588, Beijing 100049, China \\ ${ }^{\ddagger}$ State Key Laboratory of Continental Dynamics, Department of Geology, Northwest University, Xi’an, Shanxi 710069, \\ China
}

(Received 10 February 2014; accepted 17 July 2014; first published online 22 October 2014)

\begin{abstract}
High-resolution SIMS U-Pb dating of metamorphic zircons of the TTG gneisses, gneissic granitoid and amphibolites of the Lushan terrane, Taihua metamorphic complex, suggests that the metamorphism had taken place at least as early as $\sim 1.96-1.86 \mathrm{Ga}$. These new dates, along with reference data, demonstrate that the southern and middle terranes of the Trans-North China Orogen had been involved in the continent-continent collision between the Western Block and the Eastern Block of the North China Craton. This orogenic process started as early as $1.96 \mathrm{Ga}$ and lasted as late as $1.80 \mathrm{Ga}$.
\end{abstract}

Keywords: SIMS U-Pb dating, zircon, Lushan terrane, Taihua metamorphic complex, the Trans-North China Orogen.

\section{Introduction}

The continent-continent collision process is the subsequent process after subduction, which is generally characterized by clockwise $P-T$ paths, including an early prograde process and later isothermal decompression (ITD) process following peak metamorphism, recorded in metamorphic rocks, especially the Precambrian metamorphic terranes. Thus, clockwise $P-T$ paths characterized by ITD segments are considered to be one of the important indicators in recognizing plate tectonics, especially in the Earth's early history (e.g. Zhao, 2007). After reviewing metamorphic $P-T$ paths preserved in the different metamorphic terranes and combining lithological, structural, geochemical and geochronological data, Zhao et al. $(1998,2000 a, 2001,2005,2012)$ recognized three orogenic belts in the North China Craton (NCC), i.e. the Trans-North China Orogen (TNCO), the Jiao-Liao-Ji Belt and the Khondalite Belt (Fig. 1a), quite similar to present-day subduction zones.

In the last two decades, metamorphic investigations of the metamorphic terranes (e.g. Huai'an, Hengshan, Wutai, Fuping, Lüliang and Zanhuang terranes) within the northern and middle sections of the TNCO have confirmed that these terranes all record clockwise $P-T$ paths including ret-

$\dagger$ † Author for correspondence: wucm@ucas.ac.cn rograde ITD segments (Zhao, Cawood \& Lu, 1999; Zhao et al. 2000b, 2001, 2010; Guo, O'Brien \& Zhai, 2002; Xiao et al. 2011a,b). Geochronological studies suggest that the metamorphism of all these terranes occurred at $\sim 1.85 \mathrm{Ga}$ (Zhao et al. 2002, 2008a,b; Guo et al. 2005; Liu et al. 2006; Xiao et al. 2013). In recent years, geologists have been aware of the importance of the metamorphic terranes in the southern section of the TNCO, especially the Taihua metamorphic complex (Wan et al. 2006; Diwu et al. 2007, 2010; Liu et al. 2009; Xu et al. 2009; Huang et al. 2010, 2012; Jiang et al. 2011; Shi et al. 2011; Wang et al. 2012, 2013; Huang, Wilde \& Zhong, 2013; Yu et al. 2013; Lu et al. 2013). Our previous work (Lu et al. 2013) suggested that the Taihua metamorphic complex had been involved in the subduction and collision between the Western and Eastern blocks of the NCC and experienced later uplift processes during late Palaeoproterozoic time. However, our previous work focused solely on the gneissic amphibolites. In this contribution, we report detailed secondary ion mass spectroscopy (SIMS) dating of metamorphic zircons separated from the tonalite-trondhjemitegranodiorite (TTG) gneisses, gneissic granitoids and amphibolite boudins with weak or no gneissosity enclosed in the TTG gneisses, to further constrain the Palaeoproterozoic tectonometamorphic evolution of the Taihua metamorphic complex.

\section{Regional setting}

The Taihua metamorphic complex is located on the southwestern margin of the TNCO, which is comprised of five discrete terranes (Huashan, Xiaoshan, Luoning, Lushan and Wugang) scattered across the Shanxi and Henan provinces, north China (Fig. 1b). The Taihua metamorphic complex consists mainly of TTG gneisses, amphibolites, metapelitic gneisses, marbles and quartzites; experienced upperamphibolite-facies metamorphism and intense deformation; and records clockwise $P-T$ paths including ITD segments (Lu et al. 2013).

In Lushan County, Henan Province, the southwestern Taihua metamorphic complex is uncomformably covered by unmetamorphosed volcanic strata of the Xiong'er Group dated at $\sim 1.78 \mathrm{Ga}$ (He et al. 2009), and the northeastern Taihua metamorphic complex is in fault contact with the Mesoproterozoic Ruyang Group and other Neoproterozoic 

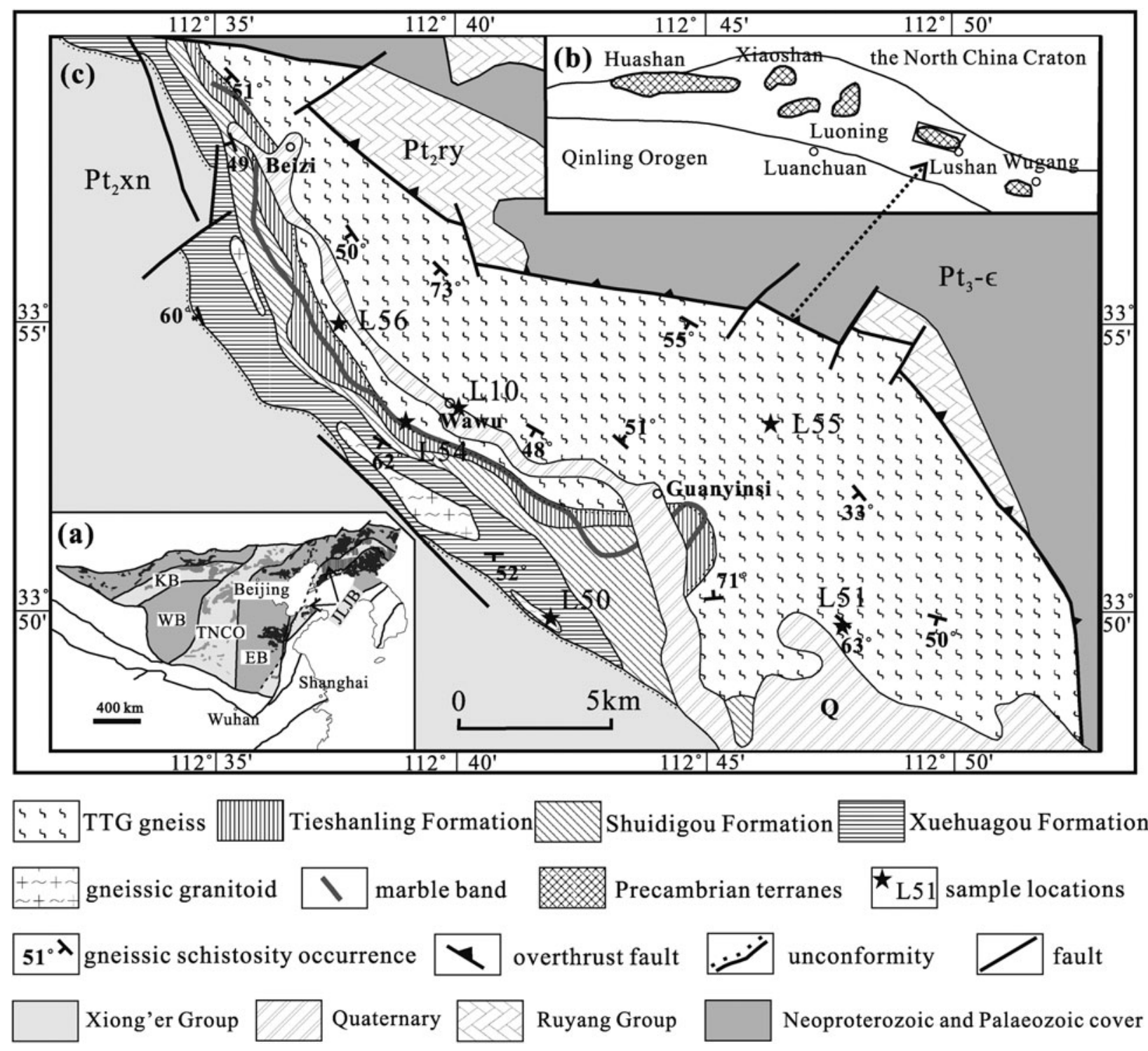

Figure 1. (a) Geological sketch map of the North China Craton (after Zhao et al. 2005); (b) the Lushan terrane in the Taihua metamorphic complex within the Trans-North China Orogen (modified after Xu et al. 2009); and (c) simplified geological map of the Lushan terrane (modified after $\mathrm{Xu}$ et al. 2009). Sample locations are shown. $\mathrm{Pt}_{2}$ ry - Ruyang Group; $\mathrm{Pt}_{2} \mathrm{Xn}-\mathrm{Xiong}^{\prime} \mathrm{Cr}_{\mathrm{Group}} \mathrm{Pt}_{3}-$ Late Proterozoic; $\epsilon$ - Cambrian; Q - Quaternary; KB - Khondalite Belt; WB - Western Block; TNCO - Trans-North China Orogen; EB - Eastern Block; JLJB - Jiao-Liao-Ji Belt.

and Palaeozoic covers. The Taihua metamorphic complex exposed in the Lushan terrane was subdivided into the Lower and Upper Taihua subgroups separated by the interstitial characteristic marble stratum exposed approximately along the Dangze River. On the northeastern side of the Dangze River is the Lower Taihua Subgroup, which is mainly composed of TTG gneisses and patchy amphibolites within the TTG gneisses. The TTG gneisses formed at $2.75-2.84 \mathrm{Ga}$ (Kröner et al. 1988; Diwu et al. 2007; Liu et al. 2009) and the protolith of the amphibolites formed at $\sim 2.73 \mathrm{Ga}$ and underwent a peak metamorphic event at $\sim 1.95 \mathrm{Ga}$ (Lu et al. 2013). On the southeastern side of the Dangze River is the Upper Taihua Subgroup, which mainly consists of metapelitic gneisses, gneissic granites and marbles. SHRIMP U-Pb dating of zircons (Wan et al. 2006) determined that the Upper Taihua Subgroup was formed during Palaeoproterozoic time (between 2.26 and $2.14 \mathrm{Ga}$ ) and experienced metamorphism at $\sim 1.85 \mathrm{Ga}$.

\section{Sample selection and analytical methods}

In this work, six representative metamorphic rock samples were selected for SIMS U-Pb dating of zircons (Fig. 1c).

Samples L10 and L56 are fine-grained garnet-bearing amphibolites showing weak or no gneissosity, occurring as short dykes within the TTG gneisses. Residual ophitic textures and intrusive relationships with the country TTG rocks are locally preserved. The amphibolites mainly consist of hornblende $(35-40 \%)+$ plagioclase $(20-15 \%)+$ quartz $(20 \%)+\operatorname{garnet}(15 \%)$ and clinopyroxene (5\%) (Fig. 2a, b).

Samples L51, L54 and L55 are grey coarse-grained TTG gneisses, and are mainly composed of plagioclase (35$53 \%)+$ quartz $(20-35 \%)+$ hornblende $(15-20 \%)$ and biotite (2-15\%) (Fig. 2c-e). Garnets are locally observed in sample L55.

Sample L50 is a gneissic granitoid collected from Limeigou Village and is mainly composed of quartz 

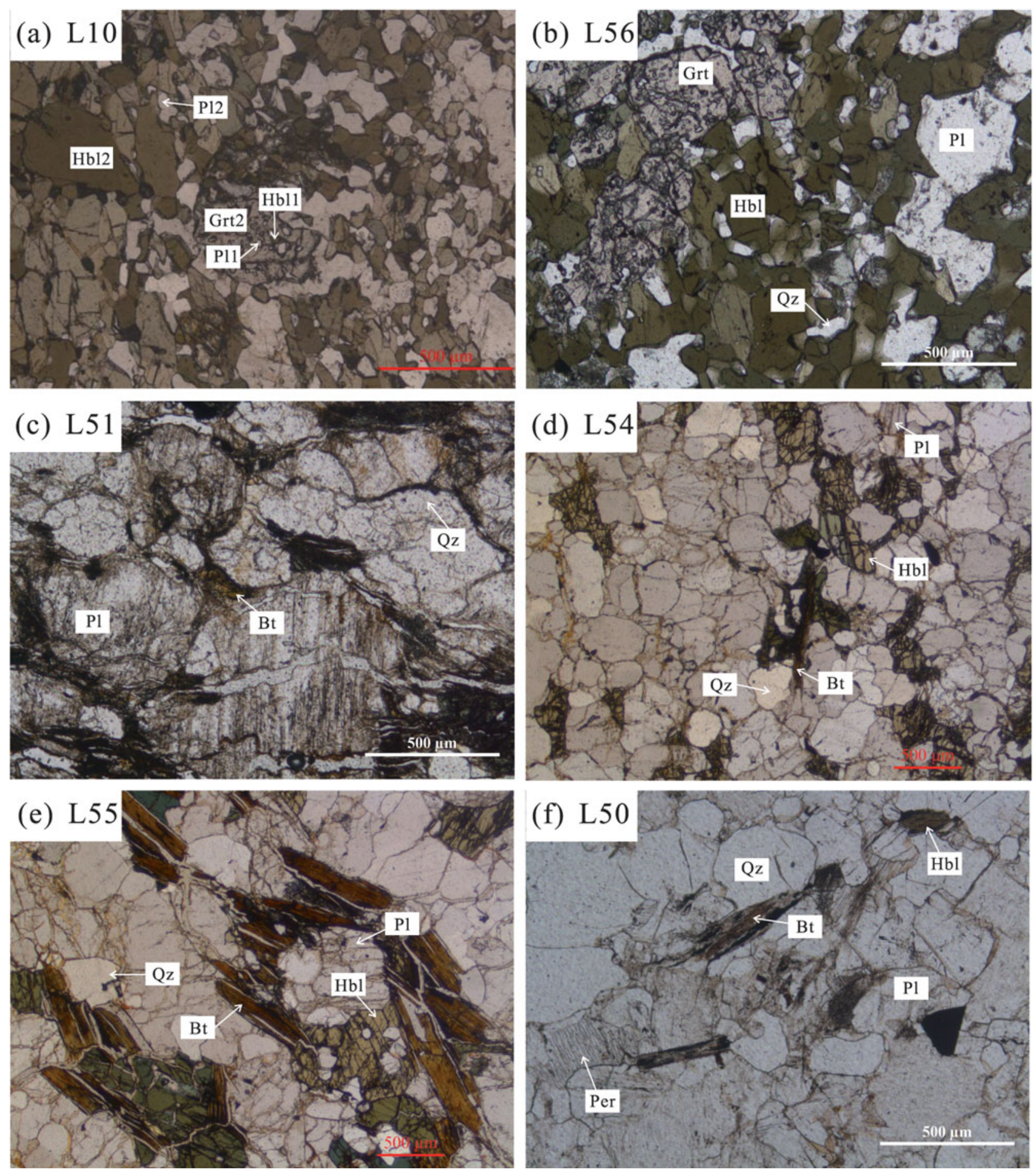

Figure 2. (Colour online) Photomicrographs of amphibolites (a, b), TTG gneisses (c, d, e) and gneissic granitoid (f). Symbols for minerals are after Whitney \& Evans (2010).

$(50 \%)+$ perthite $(35 \%)+$ plagioclase $(8 \%)+\mathrm{K}$-feldspar $(5 \%)$ and biotite $(2 \%)$ (Fig. $2 \mathrm{f})$.

Zircons for SIMS U-Pb geochronological studies were collected by conventional magnetic and density separation techniques. Zircon grains, together with the zircon standards Plešovice and Qinghu, were mounted in epoxy mounts which were then polished to section the crystals in half for analysis. Prior to the SIMS analysis, micrographs of all zircons were taken using transmitted and reflected light as well as cathodoluminescence (CL) to reveal their internal structures. Measurements of $\mathrm{U}$, Th and $\mathrm{Pb}$ isotopes were conducted us- ing a Cameca IMS 1280 large-radius SIMS at the Institute of Geology and Geophysics, Chinese Academy of Sciences in Beijing. The analytical beam was about $20 \times 30 \mu \mathrm{m}$ in size. Analytical procedures, conditions and data processing procedures are the same as those described by Li et al. (2009). Data reduction was carried out using the Isoplot/Ex v. 3.75 program (Ludwig, 2012). The SIMS zircon U-Pb dating results are listed in Table S1 in the online Supplementary Material available at http://journals.cambridge.org/geo. The uncertainties in Table S1 and on the cathodoluminescence (CL) diagrams for individual analyses are quoted at the 


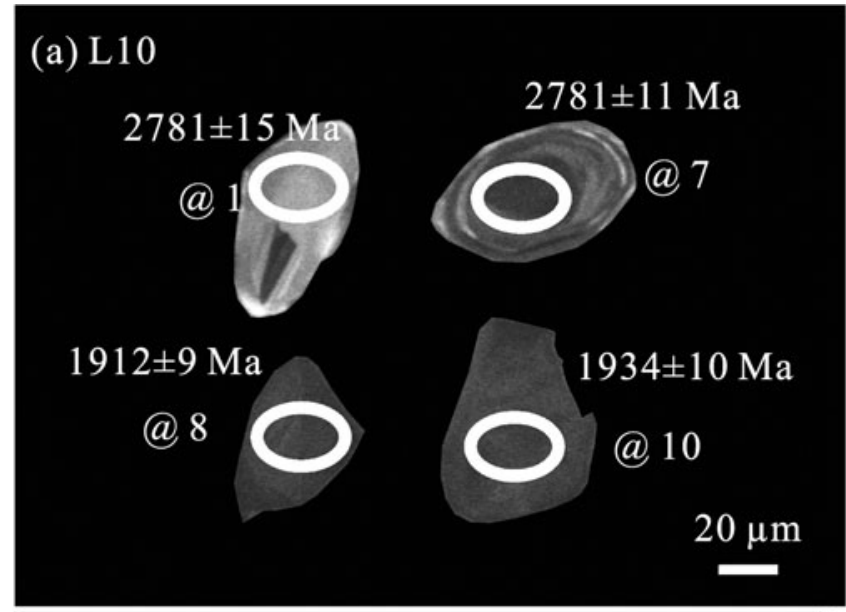

(b) L56

(c) L51
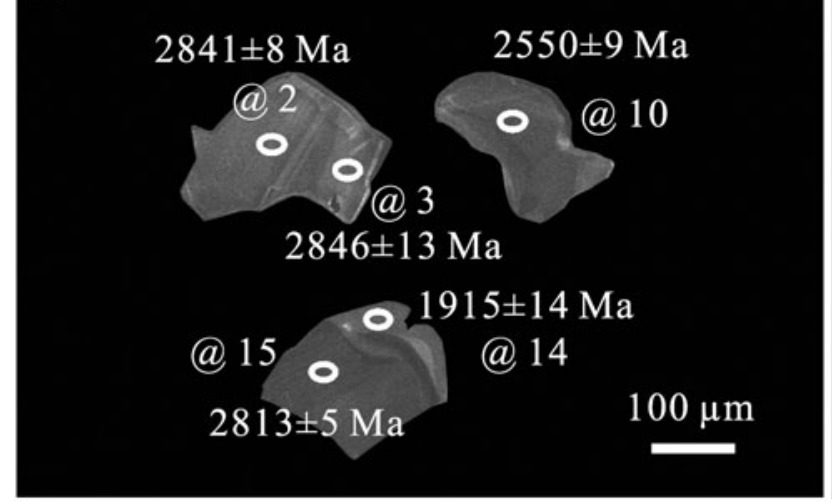

(d) L54

$1915 \pm 9 \mathrm{Ma}$

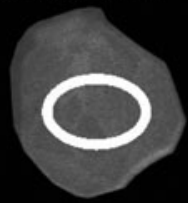

@ 1

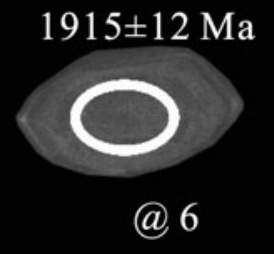

$100 \mu \mathrm{m}$
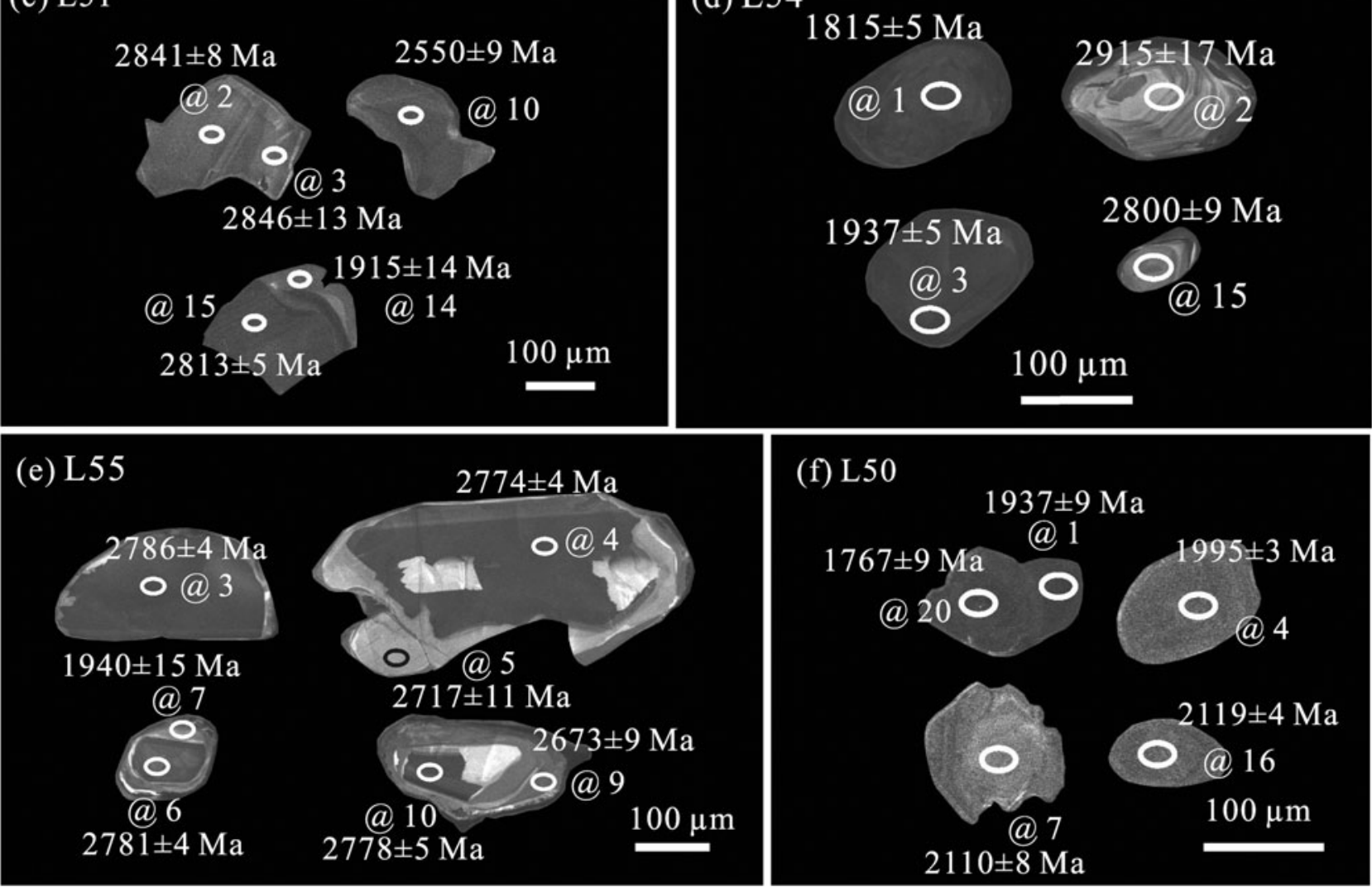

Figure 3. Representative cathodoluminescence (CL) images of zircons separated from amphibolites (a, b), TTG gneisses (c, d, e) and gneissic granitoid (f), Lushan terrane. The numbers refer to the analytical spots and the corresponding data are list in Table $\mathrm{S} 1$ in the online Supplementary Material available at http://journal.cambridge.org/geo.

$1 \sigma$ level, whereas the errors on weighted mean ages given in Figure 4 and in the text are quoted at the $95 \%$ confidence level.

In order to monitor the external uncertainties of the SIMS $\mathrm{U}-\mathrm{Pb}$ measurements calibrated against the Plešovice standard, the Qinghu zircon standard was additionally analysed as an unknown together with the unknown zircons that were mounted in mounts A2206, A2420 and A2421 during the course of this study. A total of 27 measurements were conducted on the Qinghu zircon (Table S1 in the online Supplementary Material available at http://journals.cambridge.org/geo), and the Concordia ages (Ludwig, 2012) of $159.5 \pm 2.5 \mathrm{Ma}$, $160.8 \pm 0.8 \mathrm{Ma}$ and $159.0 \pm 0.75 \mathrm{Ma}$ were obtained for the Qinghu zircon in mounts A2206, A2420 and A2421, respectively. These three measured ages define a mean of
$159.77 \pm 0.91 \mathrm{Ma}$, which is identical to the recommended value of $159.5 \pm 0.7 \mathrm{Ma}$ (Li et al. 2009), within error.

\section{Geochronological results and interpretations}

\section{4.a. Amphibolites}

Zircons separated from the amphibolites (samples L10 and L56) bear close resemblance to one another and are anhedral and round in shape, varying from 40 to $90 \mu \mathrm{m}$ in length. They are internally homogeneous with weak to medium luminescence in the CL images (Fig. 3a, b), except for a few grains in Sample L10 with weak zoning.

In Sample L10, three age groups have been recognized. The first group is represented by spots 1,7 and 16. Spots 
RAPID COMMUNICATION

371
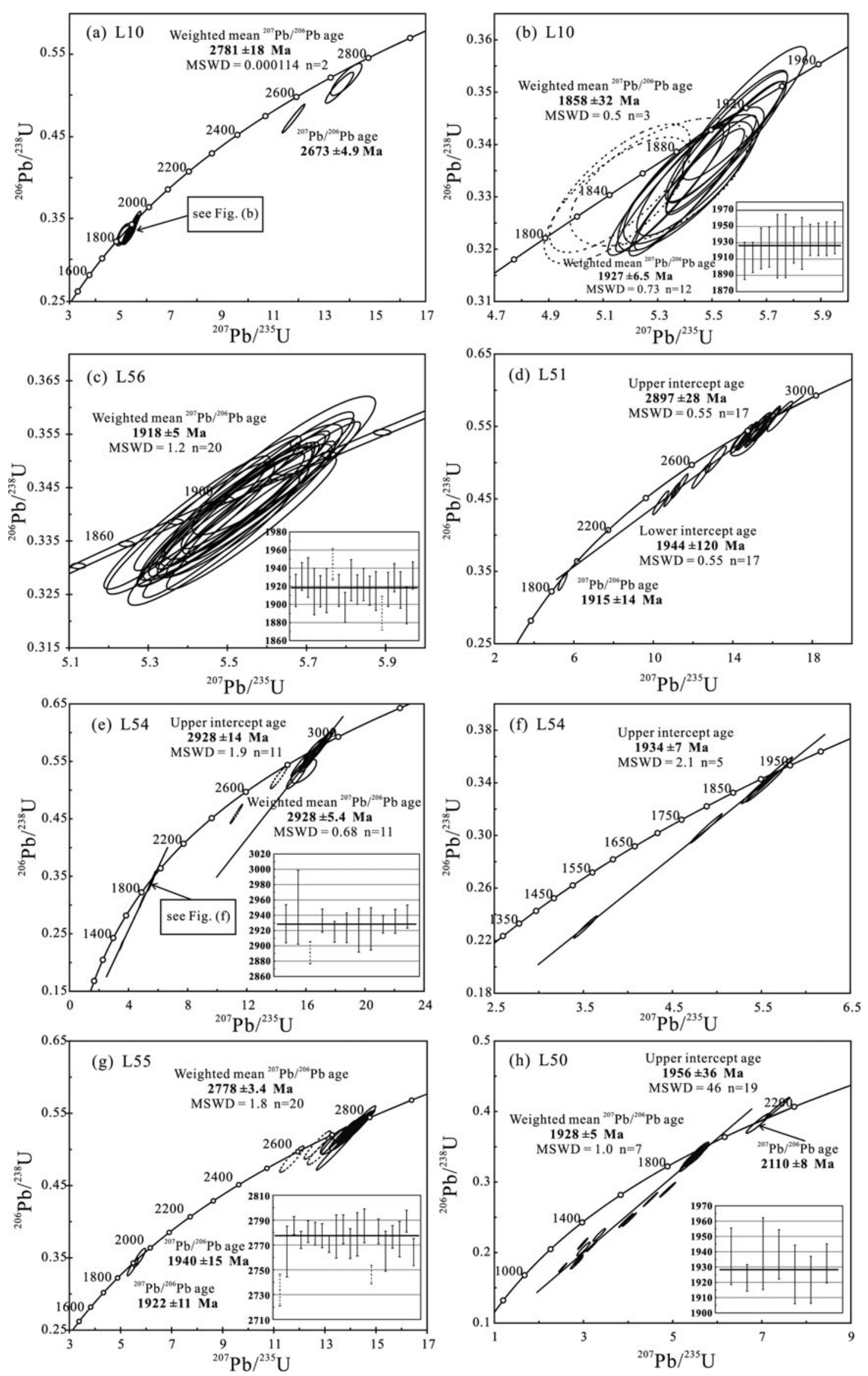

Figure 4. The U-Pb Concordia diagrams for SIMS U-Pb dating of zircons from the amphibolites (ac), TTG gneisses (deg), as well as from the gneissic granitoid $(\mathrm{h})$.

https://doi.org/10.1017/S0016756814000430 Published online by Cambridge University Press 
1 and 7 are distributed near the Concordia line (Fig. 4a) and give a weighted mean ${ }^{207} \mathrm{~Pb}-{ }^{206} \mathrm{~Pb}$ age of $2781 \pm 18 \mathrm{Ma}$ (MSWD $=0.000114$ ), possibly indicating the protolith age or possible xenocrystic grains from host TTG rocks. The second group consists of 12 spots (spots 3-6, 8-11, 13, 14, 17 and 18 ), and their $\mathrm{U}$, Th and $\mathrm{Pb}$ contents and $\mathrm{Th} / \mathrm{U}$ ratios are in the range of 189-295 ppm, 36-99 ppm, 77-122 ppm and 0.19-0.40, respectively. They plot around the Concordia curve (Fig. 4a, b), defining a weighted mean ${ }^{207} \mathrm{~Pb}-{ }^{206} \mathrm{~Pb}$ age of $1927 \pm 6.5 \mathrm{Ma}(\mathrm{MSWD}=0.73)($ Fig. $4 \mathrm{~b})$, which is interpreted as possibly the peak metamorphic age. The third group contains three spots (spots 2, 12 and 15), and their $\mathrm{U}, \mathrm{Th}$ and $\mathrm{Pb}$ contents and $\mathrm{Th} / \mathrm{U}$ ratios are in the range of $207-255 \mathrm{ppm}, 56-100 \mathrm{ppm}, 105-817 \mathrm{ppm}$ and $0.27-0.39$, respectively. They all plot near the Concordia curve, giving a weighted mean ${ }^{207} \mathrm{~Pb}-{ }^{206} \mathrm{~Pb}$ age of $1858 \pm 32 \mathrm{Ma}$ (MSWD $=0.5$ ) (Fig. 4b), possibly defining a post-peak metamorphic event.

In Sample L56, 20 spots were analysed on 20 grains. Their $\mathrm{U}$, Th and $\mathrm{Pb}$ contents and $\mathrm{Th} / \mathrm{U}$ ratios are in the range of 210-314 ppm, 36-175 ppm, 86-130 ppm and 0.13-0.58, respectively. These spots are distributed on the Concordia line and define a weighted mean ${ }^{207} \mathrm{~Pb}-{ }^{206} \mathrm{~Pb}$ age of $1918 \pm 5 \mathrm{Ma}$ $(\mathrm{MSWD}=1.2)$ (Fig. 4c), which is interpreted as possibly recording peak metamorphism.

\section{4.b. TTG gneisses}

Zircons extracted from the TTG gneisses (samples L51, L54 and L55) show diverse features. Zircons from samples L51 and L55 are transparent, anhedral and prismatic or stubby in shape varying from 90 to $570 \mu \mathrm{m}$ in length. Zircons from Sample L54 vary from 80 to $160 \mu \mathrm{m}$ in length and are obviously smaller than those from samples L51 and L55. They are classified into two different types: the first type are stubby or round in shape and are internally homogeneous with weak luminescence in CL images (Fig. 3d), indicating a possible metamorphic origin. The second type are stubby in shape and show obvious oscillatory zoning in CL images (Fig. 3d), indicating a possible magmatic origin.

Eighteen spot analyses were conducted on 16 zircon grains from Sample L51. The analytical location of spot 14 is on the rim of the zircon (Fig. 3c), plots near the Concordia curve and gives a ${ }^{207} \mathrm{~Pb}-{ }^{206} \mathrm{~Pb}$ age of $1915 \pm 14 \mathrm{Ma}$ (Fig. $4 \mathrm{~d}$ ), which is interpreted as possibly representing the metamorphic peak. The other spots show variable $\mathrm{Pb}$ loss and yield an upper intercept age of $2897 \pm 28 \mathrm{Ma}(\mathrm{MSWD}=0.55)$ (Fig. 4d), which is interpreted to be the possible protolith age of the TTG gneiss. It is noteworthy that, although the lower intercept age $1944 \pm 120 \mathrm{Ma}(\mathrm{MSWD}=0.55)$ (Fig. 4d) has a larger error, it is also consistent with the metamorphic age of spot 14.

In Sample L54, 19 spot analyses were performed on 19 zircon grains. The first group of zircons contains five spots (spot 1, 3, 9, 13 and 16), and their U, Th and $\mathrm{Pb}$ contents and $\mathrm{Th} / \mathrm{U}$ ratios are in the range of 530 1905 ppm, 10-150 ppm, 201-492 ppm and 0.02-0.12, respectively (Table S1 in the online Supplementary Material available at http://journals.cambridge.org/geo), defining an upper intercept age of $1934 \pm 7 \mathrm{Ma}(\mathrm{MSWD}=2.1$ ) (Fig. 4e, f), which is ascribed to the possible peak metamorphic age. In the second type of zircons, their U, Th and $\mathrm{Pb}$ contents and $\mathrm{Th} / \mathrm{U}$ ratios are in the range of 34 $1163 \mathrm{ppm}, 20-239 \mathrm{ppm}, 26-631 \mathrm{ppm}$ and $0.21-0.87$, respectively (Table S1 in the online Supplementary Material available at http://journals.cambridge.org/geo), and yield ${ }^{207} \mathrm{~Pb}{ }^{206} \mathrm{~Pb}$ ages ranging from 2641 to $2950 \mathrm{Ma}$. Except for spots 7 and 15, the other spots define an upper intercept age of $2928 \pm 14 \mathrm{Ma}(\mathrm{MSWD}=1.9)$ (Fig. 4e), which is coeval with the weighted mean ${ }^{207} \mathrm{~Pb}-{ }^{206} \mathrm{~Pb}$ age of $2928 \pm 5.4 \mathrm{Ma}$ $(\mathrm{MSWD}=0.68)(\mathrm{Fig} .4 \mathrm{e})$, confining the protolith age of the TTG gneiss.

Twenty-six spots of 19 zircon grains from Sample L55 were analysed. Two rim spots (spots 7 and 16) are plotted near the Concordia curve and their ${ }^{207} \mathrm{~Pb}-{ }^{206} \mathrm{~Pb}$ ages are $1940 \pm 15 \mathrm{Ma}$ and $1922 \pm 11 \mathrm{Ma}$, respectively, possibly representing the metamorphic age recorded in the TTG gneiss. The rest of the spots yield ${ }^{207} \mathrm{~Pb}-{ }^{206} \mathrm{~Pb}$ ages ranging from 2602 to $2789 \mathrm{Ma}$ with their $\mathrm{U}$, Th and $\mathrm{Pb}$ contents and $\mathrm{Th} / \mathrm{U}$ ratios in the range of $42-319 \mathrm{ppm}, 7$ $239 \mathrm{ppm}, 28-232 \mathrm{ppm}$ and $0.13-0.82$, respectively (Table $\mathrm{S} 1$ in the online Supplementary Material available at http://journals.cambridge.org/geo). Without spots 5, 9 and 14 , the rest of the data define a weighted mean ${ }^{207} \mathrm{~Pb}-{ }^{206} \mathrm{~Pb}$ age of $2778 \pm 3.4 \mathrm{Ma}(\mathrm{MSWD}=1.8$ ) (Fig. 4g), restricting the protolith age of the TTG gneiss.

\section{4.c. Gneissic granitoid}

Zircons separated from the gneissic granitoid (Sample L50) are transparent, prismatic or stubby in shape, with weak zoning in CL images and vary from 70 to $180 \mu \mathrm{m}$ in length (Fig. 3f). A total of 20 spots on 18 grains were analysed and two age groups have been recognized. The first group is represented by spots 7 and 16 . Spot 7 is plotted on the Concordia curve with a ${ }^{207} \mathrm{~Pb}-{ }^{206} \mathrm{~Pb}$ age of $2110 \pm 8 \mathrm{Ma}$, which is interpreted as the protolith age and is consistent with the result of Wan et al. (2006). Spot 16 is located above the Concordia curve, which may possibly be influenced by the tiny inclusion minerals within it. The second group of zircons show varying degrees of $\mathrm{Pb}$ loss and yield an upper intersect age of $1956 \pm 36 \mathrm{Ma}(\mathrm{MSWD}=46)($ Fig. $4 \mathrm{~h})$ in the conventional Concordia diagram, and the modest/weakest $\mathrm{Pb}$ loss zircons define a weighted mean ${ }^{207} \mathrm{~Pb}-{ }^{206} \mathrm{~Pb}$ age of $1928 \pm 5 \mathrm{Ma}(\mathrm{MSWD}=1.0)$ (Fig. 4h), which is older than those obtained by Wan et al. (2006) and is deciphered to represent the peak metamorphic age.

It is suggested that from this new high-resolution SIMS $\mathrm{U}-\mathrm{Pb}$ dating of the zircons, two periods of protolith ages of the TTG gneisses can be recognized: the first one is $\sim 2.93$ 2.90 Ga recorded in samples L51 and L54, which is older than previous studies (Kröner et al. 1988; Diwu et al. 2007; Liu et al. 2009); the second one is $2.78 \mathrm{Ga}$ recorded in Sample L55, which is in accordance with the results obtained by Diwu et al. (2010).

\section{Discussion}

Zhao et al. (2012) summarized the metamorphic chronological data obtained from the different metamorphic terranes within the TNCO, and the dataset suggests that the metamorphism occurred during $\sim 1.89-1.80$ Ga based on $\mathrm{Sm}-\mathrm{Nd}$ isochron dating of metamorphic minerals, electron microprobe analyser (EMPA) chemical dating of metamorphic monazites, ${ }^{40} \mathrm{Ar}-{ }^{39} \mathrm{Ar}$ dating of metamorphic hornblendes and a great quantity of single grain evaporation, sensitive high-resolution ion microprobe (SHRIMP) and inductively coupled plasma mass spectrometry (ICP-MS) U-Pb dating of metamorphic zircons. Furthermore, it is noted that the Wutai metamorphic terrane, in the middle segment of the TNCO, experienced metamorphism dated at about $1.91 \mathrm{Ga}$ based on $\mathrm{Sm}-\mathrm{Nd}$ isochron dating of metamorphic minerals from the garnet-bearing amphibolites, and at about $1.92 \mathrm{Ga}$ via EMPA chemical dating of metamorphic monazites from the metapelites (Liu et al. 2004). For the Lüliang metamorphic terrane, in the middle segment of the TNCO, the 


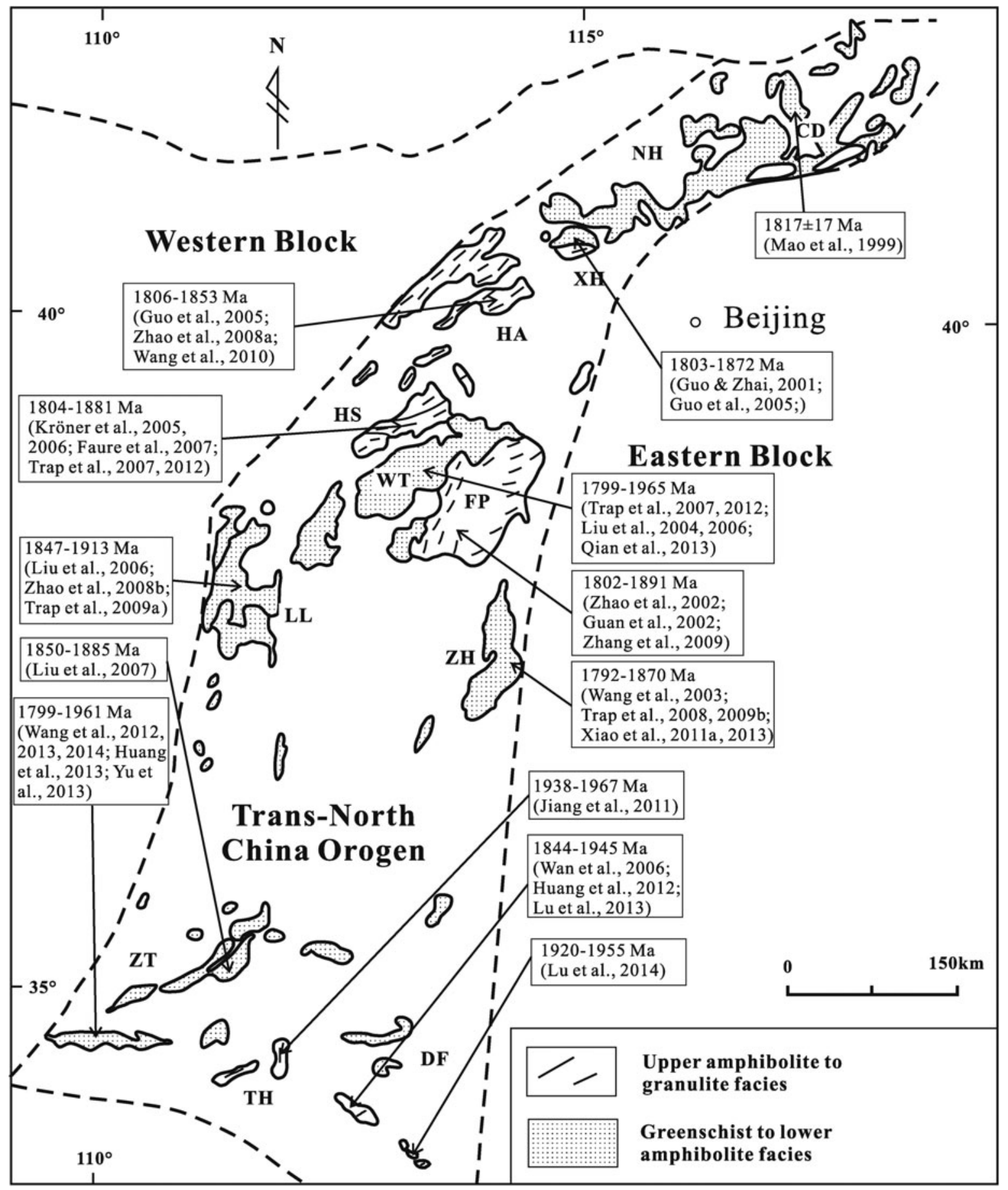

Figure 5. Sketch metamorphic ages of the metamorphic terranes within the Trans-North China Orogen (TNCO) (after Zhao \& Zhai, 2013). Abbreviations for the metamorphic complexes: CD - Chengde; DF - Dengfeng; FP - Fuping; HA - Huai'an; HS - Hengshan; LL - Lüliang; NH - Northern Hebei; TH - Taihua; WT - Wutai; XH - Xuanhua; ZH - Zanhuang; ZT - Zhongtiao.

metamorphism was dated to have occurred at about $\sim 1.90$ $1.86 \mathrm{Ga}$ via EMPA chemical dating of metamorphic monazites from the metapelites and granitic gneisses (Liu et al. 2007); the Zhongtiao metamorphic terrane, in the southern segment of the TNCO, was dated to have been metamorphosed at about 1.88 1.85 Ga through EMPA chemical dating of metamorphic monazites from the monzogranitic gneisses (Liu et al. 2007).

In recent years, metamorphic geochronological data from the Taihua metamorphic complex have also been reported (Fig. 5), including 1.84 and $1.87 \mathrm{Ga}$ ages from the Upper Taihua Subgroup, Lushan terrane by Wan et al. (2006),
$1.94 \mathrm{Ga}$ to $1.97 \mathrm{Ga}$ ages from metamorphic zircons through LA-ICP-MS dating in the Luoning terrane (Jiang et al. 2011), $1.96 \mathrm{Ga}$ to $1.82 \mathrm{Ga}$ ages through LA-ICP-MS and CAMECA SIMS U-Pb dating of metamorphic zircons and a $\sim 1.80 \mathrm{Ga}$ age obtained by ${ }^{40} \mathrm{Ar}-{ }^{39} \mathrm{Ar}$ dating of metamorphic hornblendes in the Huashan terrane (Wang et al. 2012, 2013), $1.94 \mathrm{Ga}$ to $1.86 \mathrm{Ga}$ ages through SHRIMP dating in the Huashan terrane (Huang, Wilde \& Zhong, 2013) and $1.88 \mathrm{Ga}$ to $1.87 \mathrm{Ga}$ ages through LA-ICP-MS dating of metamorphic zircons in the Huashan terrane (Yu et al. 2013). These data further suggest that the tectonometamorphic event of the TNCO started at least as early as $\sim 1.96 \mathrm{Ga}$, much earlier 
than the previously deciphered $\sim 1.85$ Ga (Zhao et al. 1998 , 2005, 2012).

Different types of rocks collected from the Upper Taihua Subgroup and the Lower Taihua Subgroup in the Lushan terrane all record an identical metamorphic event varying from $1.96 \mathrm{Ga}$ to $1.86 \mathrm{Ga}$, which is in accordance with our previous study (Lu et al. 2013). Therefore, it may be confidently concluded that the Taihua metamorphic complex obviously records an older metamorphic process than the northern metamorphic terranes of the TNCO.

Therefore, the orogenic process of the southernmost terminal of the TNCO including subduction, collision and tectonic denudation not only occurred earlier than, but lasted longer than the metamorphic terranes of the northern sections of the TNCO. Meanwhile, it is noticed that the tectonometamorphic event of the Taihua metamorphic complex was almost coeval with the collision of the Jiao-Liao-Ji Belt at $\sim 1.95$ Ga (Luo et al. 2004, 2008; Lu et al. 2006; Tam et al. 2011) and at about $\sim 1.96 \mathrm{Ga}$ of the Khondalite Belt (Yin et al. 2009, 2011; Zhou \& Geng, 2009).

The ubiquitously distributed undeformed, unmetamorphosed Palaeoproterozoic sedimentary rocks (Liu et al. 2012) and mafic dykes ( 1.77 Ga) (Wang et al. 2004, 2008; Peng et al. 2005, 2008, 2012; Peng, Zhai \& Guo, 2006) throughout the TNCO post-date the collision events of the orogenic belt.

\section{Brief conclusion}

(1) Combining available data, it is concluded that the different metamorphic rocks that crop out within the Lushan terrane, including the amphibolites, TTG gneisses and gneissic granitoid, all experienced the Palaeoproterozoic metamorphic event at about 1.96-1.86 Ga.

(2) The possible subduction and collision of the southernmost terminal of the TNCO started obviously earlier than that of the northern terranes of the TNCO.

Acknowledgements. We sincerely thank professors XianHua Li and Qiu-Li Li and Mr Ya-Nan Yang for their help in secondary ion mass spectrometry (SIMS) dating of the zircons. An anonymous referee and the editorial review greatly improved the quality of the original manuscript. This work was financially supported by the National Natural Science Foundation of China $(41225007,40872125)$ and the State Key Laboratory of Geodynamics, Northwest University (BJ11059).

\section{Supplementary material}

To view supplementary material for this article, please visit http://dx.doi.org/10.1017/S0016756814000430.

\section{References}

Diwu, C. R., Sun, Y., Ling, C. L., LiU, X. M. \& WanG, H. L. 2007. Zircon U-Pb ages and Hf isotopes and their geological significance of Yiyang TTG gneisses from Henan province, China. Acta Petrologica Sinica 23, 253-62 (in Chinese with English abstract).

Diwu, C. R., Sun, Y., Ling, C. L. \& WANG, H. L. 2010. LA-(MC)-ICPMS U-Pb zircon geochronology and LuHf isotope compositions of the Taihua complex on the southern margin of the North China Craton. Chinese Science Bulletin 55, 2557-71.

Faure, M., Trap, P., Lin, W., Monié, P. \& Bruguier, O. 2007. Polyorogenic evolution of the Paleoproterozoic Trans-North China Belt, new insights from the
Lüliangshan-Hengshan-Wutaishan and Fuping massifs. Episodes 30, 1-12.

GuAn, H., Sun, M., Wilde, S. A., Zhou, X. H. \& ZHAI, M. G. 2002. SHRIMP U-Pb zircon geochronology of the Fuping Complex: implications for formation and assembly of the North China Craton. Precambrian Research 113, $1-18$.

GuO, J. H., O’BRIEN, P. J. \& ZHAI, M. G. 2002. High-pressure granulites in the Sanggan area, North China Craton: metamorphic evolution, P-T paths and geotectonic significance. Journal of Metamorphic Geology 20, 741-56.

GuO, J. H., Sun, M., CHEN, F. K. \& ZHAI, M. G. 2005. Sm$\mathrm{Nd}$ and SHRIMP U-Pb zircon geochronology of highpressure granulites in the Sanggan area, North China Craton: timing of Paleoproterozoic continental collision. Journal of Asian Earth Science 24, 629-42.

GuO, J. H. \& ZHAI, M. G. 2001. Sm-Nd age dating of highpressure granulites and amphibolite from Sanggan area, North China Craton. Chinese Science Bulletin 46, 10611.

He, Y. H., Zhao, G. C., Sun, M. \& XiA, X. P. 2009. SHRIMP and LA-ICP-MS zircon geochronology of the Xiong'er volcanic rocks: implications for the PaleoMesoproterozoic evolution of the southern margin of the North China Craton. Precambrian Research 168, 213-22.

HuAnG, X. L., NiU, Y. L., Xu, Y. G., YANG, Q. J. \& ZhONG, J. W. 2010. Geochemistry of TTG and TTG-like gneisses from Lushan-Taihua complex in the southern North China Craton: implications for late Archean crustal accretion. Precambrian Research 182, 43-56.

HuANG, X. L., WiLDE, S. A. \& ZHONG, J. W. 2013. Episodic crustal growth in the southern segment of the TransNorth China Orogen across the Archean-Proterozoic boundary. Precambrian Research 233, 337-57.

HuANG, D. M., ZhANG, D. H., WANG, S. Y., ZHANG, Y. X., DONG, C. Y., LIU, D. Y. \& WAN, Y. S. 2012. 2.3 Ga magmatism and $1.94 \mathrm{Ga}$ metamorphism in the Xiatang area, southern margin of the North China Craton - evidence from whole-rock geochemistry and zircon geochronology and Hf isotopes. Geological Review 58, 565-76 (in Chinese with English abstract).

Jiang, Z. S., Wang, G. D., XiaO, L. L., DiwU, C. R., LU, J. S. \& WU, C. M. 2011. Paleoproterozoic metamorphic $P-T-t$ path and tectonic significance of the Luoning metamorphic complex at the southern terminal of the TransNorth China Orogen, Henan Province. Acta Petrologica Sinica 27, 3701-17 (in Chinese with English abstract).

Kröner, A., COMPSton, W., ZhANG, G. W., GuO, A. L. \& TODT, W. 1988. Age and tectonic setting of Late Archean greenstone-gneiss terrain in Henan Province, China, as revealed by single-grain zircon dating. Geology 16, 21115 .

Kröner, A., Wilge, S. A., LI, J. H. \& WANG, K. Y. 2005. Age and evolution of a late Archean to early Palaeoproterozoic upper to lower crustal section in the Wutaishan/Hengshan/Fuping terrain of northern China. Journal of Asian Earth Sciences 24, 577-95.

Kröner, A., Wilge, S. A., ZhaO, G. C., O’Brien, P. J., Sun, M., LiU, D. Y., WAN, Y. S., LIU, S. W. \& GUO, J. H. 2006. Zircon geochronology of mafic dykes in the Hengshan Complex of northern China: evidence for late Palaeoproterozoic rifting and subsequent high pressure event in the North China Craton. Precambrian Research 146, 45-67.

Li, X. H., LiU, Y., LI, Q. L., GuO, C. H. \& Chamberlain, K. R. 2009. Precise determination of Phanerozoic zircon $\mathrm{Pb} / \mathrm{Pb}$ age by multi-collector SIMS without external 
standardization. Geochemistry Geophysics Geosystems 10, Q04010. doi: 10.1029/cGC002400.

LiU, S. W., SHU, G. M., PAN, Y. M. \& DANG, Q. N. 2004. Electron-microprobe dating of monazite and metamorphic age of Wutai Group, Wutai Mountains. Geological Journal of China Universities 10, 356-63 (in Chinese with English abstract).

LiU, D. Y., Wilde, S. A., Wan, Y. S., Wang, S. Y., VAlley, J. W., Kita, N., DONG, C. Y., XIE, H. Q., YANG, C. X., ZhANG, Y. X. \& GAO, L. Z. 2009. Combined U-Pb, hafnium and oxygen isotope analysis of zircons from meta-igneous rocks in the southern North China Craton reveal multiple events in the Late Mesoarchean-Early Neoarchean. Chemical Geology 261, 140-51.

LiU, S. W., Zhang, C., LiU, C. H., LI, Q. G., LÜ, Y. J., YU, S. Q., TIAN, W. \& FenG, Y. G. 2007. EPMA Th-U-Pb dating of monazite for Zhongtiao and Lüliang Precambrian metamorphic complexes. Earth Science Frontiers 14, 64-74 (in Chinese with English abstract).

LiU, C. H., ZhaO, G. C., LiU, F. L., Sun, M., Zhang, J. \& YIN, C. Q. 2012. Zircons U-Pb and Lu-Hf isotopic and whole-rock geochemical constraints on the Gantaohe Group in the Zanhuang Complex: implications for the tectonic evolution of the Trans-North China Orogen. Lithos 146-147, 80-92.

LiU, S. W., ZhaO, G. C., Wilde, S. A., Shu, G. M., Sun, M., LI, Q. G., TIAN, W. \& ZHANG, J. 2006. Th-U-Pb monazite geochronology of the Lüliang and Wutai Complexes: constraints on the tectonothermal evolution of the TransNorth China Orogen. Precambrian Research 148, 20524.

Lu, J. S., Wang, G. D., Wang, H., Chen, H. X. \& Wu, C. M. 2013. Metamorphic P-T-t paths retrieved from the amphibolites, Lushan terrane, Henan Province and reappraisal of the Paleoproterozoic tectonic evolution of the Trans-North China Orogen. Precambrian Research 238, 61-77.

Lu, J. S., Wang, G. D., Wang, H., Chen, H. X. \& Wu, C. M. 2014. Palaeoproterozoic metamorphic evolution and geochronology of the Wugang block, southeastern terminal of the Trans-North China Orogen. Precambrian Research 251, 197-211.

LU, Y. P., WU, F. Y., GUO, J. H., WILDE, S. M., YANG, J. H., LIU, X. M. \& ZHANG, X. O. 2006. Zircon U-Pb geochronological constraints on the Paleoproterozoic crustal evolution of the Eastern block in the North China Craton. Precambrian Research 146, 138-64.

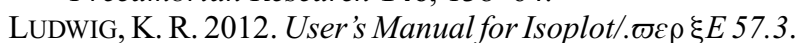
Berkeley Geochronology Centre Special Publication no. 5.

Luo, Y., Sun, M., ZhaO, G. C., Li, S. Z., Ayers, J. C., XIA, X. P. \& ZHANG, J. H. 2008. A comparison of U-Pb and $\mathrm{Hf}$ isotopic compositions of detrital zircons from the North and South Liaohe Groups: constraints on the evolution of the Jiao-Liao-Ji Belt, North China Craton. Precambrian Research 163, 279-306.

LuO, Y., Sun, M., ZhaO, G. C., LI, S. Z., Xu, P., Ye, K. \& XIA, X. P. 2004. LA-ICP-MS U-Pb zircon ages of the Liaohe Group in the Eastern Block of the North China Craton: constraints on the evolution of the Jiao-Liao-Ji Belt. Precambrian Research 134, 349-71.

MaO, D. B., Zhong, C. T., Chen, Z. H., Lin, Y. X., Li, H. M. \& HU, X. D. 1999. Isotopic ages and geological implications of high-pressure mafic granulites in the northern Chengde area, Hebei Province, China. Acta Petrologica Sinica 15, 524-34 (in Chinese with English abstract).
Peng, P., LiU, F., Zhai, M. G. \& GuO, J. H. 2012. Age of the Miyun dyke swarm: constraints on the maximum depositional age of the Changcheng System. Chinese Science Bulletin 57, 105-10.

Peng, P., Zhai, M. G., ERnst, R. E., GuO, J. H., LiU, F. \& Hu, B. 2008. A $1.78 \mathrm{Ga}$ large igneous province in the North China craton: the Xiong'er Volcanic Province and the North China dyke swarm. Lithos 101, 260-80.

Peng, P., ZhaI, M. G. \& GuO, J. H. 2006. 1.80-1.75 Ga mafic dyke swarms in the central North China craton: implications for a plume-related break-up event. In Dyke Swarms - Time Markers of Crustal Evolution (eds E. Hanski, S. Mertanen, T. Rämö \& J. Vuollo), pp. 99 112. London: Taylor \& Francis.

Peng, P., Zhai, M. G., Zhang, H. F. \& GuO, J. H. 2005. Geochronological constraints on the Paleoproterozoic evolution of the North China Craton: SHRIMP zircon ages of different types of mafic dikes. International Geology Review 47, 492-508.

Qian, J. H., Wei, C. J., Zhou, X. W. \& Zhang, Y. H. 2013. Metamorphic P-T paths and new zircon $\mathrm{U}-\mathrm{Pb}$ age data for garnet-mica schist from the Wutai Group, North China Craton. Precambrian Research 233, 282-96.

SHI, Y., YU, J. H., XU, X. S., TANG, H. F., QIU, J. S. \& CHEN, L. H. 2011. U-Pb ages and Hf isotope compositions of zircons of Taihua Group in Xiaoqinling area,Shaanxi Province. Acta Petrologica Sinica 27, 3095-108 (in Chinese with English abstract).

Tam, P. Y., ZhaO, G. C., LiU, F. L., Zhou, X. W., Sun, M. \& LI, S. Z. 2011. Timing of metamorphism in the Paleoproterozoic Jiao-Liao-Ji Belt: new SHRIMP U-Pb zircon dating of granulites, gneisses and marbles of the Jiaobei massif in the North China Craton. Gondwana Research 19, 150-62.

Trap, P., Faure, M., Lin, W., Breton, N. L. \& Monié, P. 2012. Paleoproterozoic tectonic evolution of the TransNorth China Orogen: toward a comprehensive model. Precambrian Research 222-223, 191-211.

Trap, P., Faure, M., Lin, W. \& MefFre, S. 2009a. The Lüliang Massif: a key area for the understanding of the Palaeoproterozoic Trans-North China Belt, North China Craton. In Palaeoproterozoic Supercontinents and Global Evolution (eds S. M. Reddy, R. Mazumder, D. A. D. Evans \& A. S. Collins), pp. 99-125. Geological Society of London, Special Publication no. 323.

Trap, P., Faure, M., Lin, W. \& Monié, P. 2007. Late Paleoproterozoic (1900-1800 Ma) nappe stacking and polyphase deformation in the Hengshan-Wutaishan area: implications for the understanding of the Trans-NorthChina Belt, North China Craton. Precambrian Research 156, 85-106.

Trap, P., Faure, M., Lin, W., Monié, P. \& Bruguier, O. 2008. Contrasted tectonic styles for the Paleoproterozoic evolution of the North China Craton: evidence for a $2.1 \mathrm{Ga}$ thermal and tectonic event in the Fuping Massif. Journal of Structural Geology 30, 1109-25.

Trap, P., Faure, M., Lin, W., Monié, P., Mefrre, S. \& Melleton, J. 2009b. The Zanhuang Massif, the second and eastern suture zone of the Paleoproterozoic TransNorth China Orogen. Precambrian Research 172, 8098.

WAn, Y. S., Wilde, S. A., LiU, D. Y., YAnG, C. X., Song, B. \& YIN, X. Y. 2006. Further evidence for $\sim 1.85 \mathrm{Ga}$ metamorphism in the central Zone of the north China Craton: SHRIMP U-Pb dating of zircons from metamorphic rocks in the Lushan area, Henan Province. Gondwana Research 9, 189-97. 
WANG, Y. J., FAN, W. M., ZHANG, Y. \& GUO, F. 2003. Structural evolution and ${ }^{40} \mathrm{Ar} /{ }^{39} \mathrm{Ar}$ dating of the Zanhuang metamorphic domain in the North China Craton: constraints on Paleoproterozoic tectonothermal overprinting. Precambrian Research 122, 159-82.

WANG, Y. J., FAN, W. M., ZhanG, Y. H., GUO, F., ZhaNG, H. \& PENG, P. 2004. Geochemical ${ }^{40} \mathrm{Ar} /{ }^{39}$ Ar geochronological and $\mathrm{Sr}-\mathrm{Nd}$ isotopic constraints on the origin of Paleoproterozoic mafic dikes from the southern Taihang Mountains and implications for the ca. $1800 \mathrm{Ma}$ event of the North China Craton. Precambrian Research 135, 55-77.

Wang, G. D., Lu, J. S., Wang, H., Chen, H. X., Xiao, L. L., DIwU, C. R., JI, J. Q. \& WU, C. M. 2013. LAICP-MS U-Pb dating of zircons and ${ }^{40} \mathrm{Ar} /{ }^{39} \mathrm{Ar}$ dating of amphiboles of the Taihua Metamorphic Complex, Mt. Huashan, southern terminal of the Palaeoprotorozoic Trans-North China Orogen. Acta Petrologica Sinica 29, 3099-114 (in Chinese with English abstract).

Wang, G. D., Wang, H., Chen, H. X., Lu, J. S. \& Wu, C. M. 2014. Metamorphic evolution and zircon U-Pb geochronology of the Mts. Huashan amphibolites: insights into the Palaeoproterozoic amalgamation of the North China Craton. Precambrian Research 235, 100-14.

Wang, G. D., Wang, H., Chen, H. X., LU, J. S., XiaO, L. L. \& WU, C. M. 2012. U-Pb dating of zircons from metamorphic rocks of the Taihua Metamorphic Complex, Mt. Huashan, southern terminal of the Trans-North China Orogen. Acta Geologica Sinica 86, 1541-51 (in Chinese with English abstract).

Wang, J., Wu, Y. B., GaO, S., Peng, M., LiU, X. C., ZhaO, L. S., ZhOU, L., Hu, Z. C., Gong, H. J. \& LiU, Y. S. 2010. Zircon $\mathrm{U}-\mathrm{Pb}$ and trace element data from rocks of the Huai'an Complex: new insights into the late Paleoproterozoic collision between the Eastern and Western Blocks of the North China Craton. Precambrian Research 178, 59-71.

Wang, Y. J., ZhaO, G. C., CaWood, P. A., Fan, W. M., PENG, T. P. \& SuN, L. H. 2008. Geochemistry of Paleoproterozoic $(\sim 1770 \mathrm{Ma})$ mafic dikes from the TransNorth China Orogen and tectonic implications. Journal of Asian Earth Sciences 33, 61-77.

Whitney, D. L \& Evans, B. W. 2010. Abbreviations for names of rock-forming minerals. American Mineralogist 95, 185-87.

XiaO, L. L., JiAnG, Z. S., WANG, G. D., WAN, Y. S., WANG, T. $\&$ WU, C. M. 2011a. Metamorphic reaction textures and metamorphic $P$-T- $t$ loops of the Precambrian Zanhuang metamorphic complex, Hebei, North China. Acta Petrologica Sinica 27, 982-1002 (in Chinese with English abstract).

XiaO, L. L., Wang, G. D., Wang, H., Jiang, Z. S., DiwU, C. R. \& WU, C. M. 2013. Zircon U-Pb geochronology of the Zanhuang metamorphic complex: reappraisal of the Paleoproterozoic amalgamation of the TransNorth China Orogen. Geological Magazine 150, 75664.

XiaO, L. L., Wu, C. M., ZhaO, G. C., Guo, J. H. \& Ren, L. D. $2011 b$. Metamorphic $P-T$ paths of the Zanhuang amphibolites and metapelites: constraints on the tectonic evolution of the Paleoproterozoic Trans-North China Orogen. International Journal of Earth Sciences 100, 717-39.

Xu, X. S., Griffin, W. L., Ma, X., O’ReILly, S. Y., He, Z. Y. \& ZHANG, C. L. 2009. The Taihua group on the southern margin of the North China craton: further insights from $\mathrm{U}-\mathrm{Pb}$ ages and $\mathrm{Hf}$ isotope compositions of zircons. Mineralogy and Petrology 97, 43-59.
Yin, C. Q., ZhaO, G. C., GuO, J. H., Sun, M., XiA, X. P., ZHOU, X. W. \& LIU, C. H. 2011. U-Pb and Hf isotopic study of zircons of the Helanshan Complex: constrains on the evolution of the Khondalite Belt in the Western Block of the North China Craton. Lithos 122, 25-38.

Yin, C. Q., ZHAO, G. C., SUN, M., XIA, X. P., WEI, C. J. \& LEUNG, W. H. 2009. LA-ICP-MS U-Pb zircon ages of the Qianlishan Complex: constrains on the evolution of the Khondalite Belt in the Western Block of the North China Craton. Precambrian Research 174, 78-94.

YU, X. Q., LIU, J. L., LI, C. L., CHEN, S. Q. \& DAI, Y. P. 2013. Zircon U-Pb dating and $\mathrm{Hf}$ isotope analysis on the Taihua Complex: constraints on the formation and evolution of the Trans-North China Orogen. Precambrian Research 230, 31-44.

Zhang, J., ZhaO, G. C., Li, S. Z., Sun, M., Wilde, S. A., LIU, S. W. \& YIN, C. Q. 2009. Polyphase deformation of the Fuping Complex, Trans-North China Orogen: structures, SHRIMP U-Pb zircon ages and tectonic implications. Journal of Structural Geology 31, 177-93.

ZHAO, G. C. 2007. When did the plate tectonics begin on the North China Craton? Insights from the metamorphism. Earth Science Frontiers 14, 19-32.

Zhao, G. C., CAWOOD, P. A., LI, S. Z., Wilde, S. A., Sun, M., ZHANG, J., HE, Y. H. \& YIN, C. Q. 2012. Amalgamation of the North China Craton: key issues and discussion. Precambrian Research 222-223, 55-76.

ZhaO, G. C., Cawood, P. A. \& LU, L. Z. 1999. Petrology and $P-T$ history of the Wutai amphibolites: implications for tectonic evolution of the Wutai Complex, China. Precambrian Research 93, 181-99.

ZhaO, G. C., Cawood, P. A., Wilde, S. A., \& LU, L. Z. 2001. High-pressure granulites (retrograded eclogites) from the Hengshan Complex, North China Craton: petrology and tectonic implications. Journal of Petrology 42, 1141-70.

Zhao, G. C., CAWood, P. A., Wilde, S. A., Sun, M. \& Lu, L. Z. $2000 a$. Metamorphism of basement rocks in the Central Zone of the North China Craton: implications for Paleoproterozoic tectonic evolution. Precambrian Research 103, 55-88.

ZhaO, G. C., Sun, M., WILdE, S. A. \& LI, S. Z. 2005. Neoarchaean to Palaeoproterozoic evolution of the North China Craton: key issues revisited. Precambrian Research 136, 177-202.

ZhaO, G. C., Wilde, S. A., CAWOOD, P. A. \& LU, L. Z. 1998. Thermal evolution of the Archaean basement rocks from the eastern part of the North China Craton and its bearing on tectonic setting. International Geology Review 40, 706-21.

ZhaO, G. C., Wilde, S. A., CAWOOD, P. A. \& LU, L. Z. $2000 b$. Petrology and $P-T$ path of the Fuping mafic granulites: implications for tectonic evolution of the central zone of the North China Craton. Journal of Metamorphic Geology 18, 375-91.

ZHAO, G. C., WILDE, S. A., CAWOOD, P. A. \& SUN, M. 2002. SHRIMP U-Pb zircon ages of the Fuping Complex: implications for accretion and assembly of the North China Craton. American Journal of Science 302, 191226.

ZhaO, G. C., Wilde, S. A., Sun, M., GuO, J. H., KrÖNER, A., LI, S. Z., LI, X. P. \& WU, C. M. 2008a. SHRIMP $\mathrm{U}-\mathrm{Pb}$ zircon geochronology of the Huai'an Complex: constraints on Late Archean to Paleoproterozoic crustal accretion and collision of the Trans-North China Orogen. American Journal of Science 308, 270-303.

ZhaO, G. C., Wilde, S. A., Sun, M., LI, S. Z., LI, X. P. \& ZHANG, J. 2008b. SHRIMP U-Pb zircon ages of 
granitoid rocks in the Lüliang Complex: implications for the accretion and evolution of the Trans-North China Orogen. Precambrian Research 160, 213-26.

ZhaO, G. C., YIN, C. Q., GuO, J. H., Sun, M., LI, S. Z., LI, X. P., WU, C. M. \& LIU, C. H. 2010. Metamorphism of the Lüliang amphibolite: implications for the tectonic evolution of the North China Craton. American Journal of Science 310, 1480502.
ZHAO, G. C. \& ZHAI, M. G. 2013. Lithotectonic elements of Precambrian basement in the North China Craton: review and tectonic implications. Gondwana Research 23, $1207-40$.

ZHOU, X. W. \& GeNG, Y. S. 2009. Metamorphic age of the khondalite series in Helanshan region: constraints on the evolution of the western block in the North China Craton. Acta Petrologica Sinica 25, 1843-52 (in Chinese with English abstract). 